\title{
RELIGIÃO VIVIDA E TEOLOGIA PRÁTICA: POSSIBILIDADES DE RELACIONAMENTO NO CONTEXTO BRASILEIRO *
}

\author{
Living Religion and Practical Theology: Possibilities of Relationship
} in the Brazilian Context

Júlio Cézar Adam **

RESUMO: O conceito de religião vivida surge em meados do século $X X$ como resultado da chamada virada empírica nos estudos da sociologia da religião, como uma forma de observar e ler o contexto da vida e da religião fora do âmbito estritamente institucional, normativo, tradicional e dogmático da Igreja. Com base nesse desenvolvimento, a religião vivida passa a ser para a teologia prática, em especial no contexto europeu, ao mesmo tempo uma hermenêtica, uma chave de leitura do contexto, mas também um fenômeno de manifestação do religioso e da religião de maneira mais ampla. Este artigo pretende, a partir de uma revisão bibliográfica, contribuir na reflexão sobre a hermenêutica e o fenômeno da religião vivida em sua relação com a teologia prática, considerando também o contexto brasileiro e latino-americano, onde a religião, o religioso existem de forma efusiva, mas pouco observada a partir do conceito de uma religião vivida. $\mathrm{O}$ artigo está organizado da seguinte forma: Primeiramente, aborda-se alguns aspectos relevantes nas pesquisas sobre religião e cultura, como pano de fundo do que veio posteriormente a definir-se como religião vivida. Em seguida, se trata de conceituar religião vivida na sua relação com a teologia prática. No terceiro ponto do artigo reflete-se sobre as possibilidades de uma religião vivida no contexto brasileiro e latino-americano. Por fim, são apresentadas algumas consequências desse estudo para a teologia prática.

PALAVRAS-CHAVE: Religião vivida. Teologia Prática. Religião. Brasil.

\footnotetext{
* Uma versão mais ampla dessa discussão foi inicialmente disponibilizada como "draft" no site academia.edu, como forma de propiciar o debate sobre o assunto. O que se apresenta aqui é resultando desse processo, com agradecimento especial à leitura crítica do professor César Rios.

** Faculdades EST, São Leopoldo, Rio Grande do Sul, Brasil.
} 
ABSTRACT: The concept of living religion has risen from the mid-twentieth century as a result of the so-called empirical uprising in studies of the sociology of religion, as a way of observing and reading the context of life and religion outside the framework of strictly institutional, normative, traditional, and dogmatic setup of the church. On this basis of development the living religion becomes the practical theology, especially in the European context and at the same time, not only a hermeneutical key to the reading of the context, but also a phenomenon of manifestation of the religious and of the religion occur in a broader way. This article intends from a bibliographical review to contribute to the reflection on the hermeneutics and the phenomenon of living religion in its relationship with the practical theology, while considering the Brazilian and the Latin American context where the religion and the religious exist in an effusive way; however it is rarely observed from the concept of a living religion. This article is organized as follows: first, some relevant aspects are discussed with regard to the research on religion and culture as the background for what later has come to be defined as the living religion. Secondly, it deals with conceptualization of living religion in its relation with the practical theology. In the third section of this article, it reflects on the possibilities of a living religion in the context of Brazil and Latin America. Finally, it presents some of the consequences from this study for the practical theology.

KEYWORDS: Living Religion. Practical Theology. Religion. Brazil.

\section{Introdução}

Ta segunda metade do século XX ocorre uma deliberada mudança 1 de perspectiva na teologia prática. Ela passa a dar atenção especial para a realidade não apenas da Igreja e do ministério, mas também da cultura, da sociedade e da religião, de modo geral, como âmbito empírico a ser considerado pela disciplina. A maneira como o indivíduo vive sua religiosidade e espiritualidade dentro e fora do âmbito institucional e tradicional da Igreja ou outra tradição religiosa passa a ter grande relevância, relacionando ou não sua vivência com um sistema religioso. O conceito de religião vivida surge dessa virada empírica como uma forma de observar e ler o contexto da vida e da religião fora do âmbito estritamente institucional, normativo, tradicional e dogmático da Igreja. Religião vivida, portanto, passa a ser para a teologia prática ao mesmo tempo uma hermenêutica, uma chave de leitura do contexto, mas também um fenômeno de manifestação do religioso e da religião de maneira mais ampla. Este artigo pretende contribuir na reflexão sobre a hermenêutica e o fenômeno da religião vivida em sua relação com a teologia prática, considerando também o contexto brasileiro e latino-americano, onde a religião, o religioso e também a religião vivida existem de forma efusiva, mas pouco observada a partir do conceito de uma religião vivida.

$\mathrm{O}$ autor desse artigo tomou conhecimento da possibilidade e do interesse pela investigação de manifestações e vivências religiosas fora do âmbito 
institucional eclesiástico e teológico, na Alemanha, quando realizava seu doutorado, na Universidade de Hamburgo, no final da década de 90 inícios dos anos 2000. O professor Hans-Martin Gutmann (1998; 2013) havia chegado na universidade e trazia consigo suas pesquisas sobre a possível relação entre teologia e cultura pop, em especial o cinema, mas também a música, o jazz e a literatura. Este diálogo entre âmbitos tão distintos soava como algo inusitado, ao mesmo tempo fascinante, pois possibilitava investigar âmbitos de interesse: a teologia e a cultura pop. As primeiras referências onde encontrou-se explicitamente o conceito de religião vivida foram os estudos de Failing e de Heimbrock (1998) e Gräb (1995, 2000; 2002; 2006; GR ÄB, W.; et al., 2006). Naquele momento, não se percebia que no contexto brasileiro e latino-americano, um contexto onde a religião e o religioso estão muito presentes, também pulsava algo como uma religião vivida fora das instituições religiosas e que vários estudos, mesmo não usando esse conceito, em diferentes direções, analisavam a religião e o religioso de forma semelhante às investigações da religião vivida. Como exemplos, podemos listar estudos sobre a religiosidade popular (SÜSS, 1979), sobre formas de sincretismo e hibridismo religioso (ALLTMANN, W.; ALTMANN, L., 2000; BOBSIN, 1997, 2016; ZWETSCH; BOBSIN, 1999), sobre a relação entre teologia e literatura (MAGALHÃES, 2000; WESTHELLE, 2011), música popular brasileira (CALVANI, 1998), cinema (SANTOS, 2002; 2014; ADAM, 2017; 2018), entre outras relações, como veremos mais detalhadamente adiante.

Com a conclusão do doutorado na Alemanha, houve o envio por parte da igreja desse autor para seu primeiro campo ministerial. Contra todas as suas expectativas e interesses profissionais e pessoais, seu primeiro campo de trabalho foi a capelania escolar, no sul do Brasil. O autor tornou-se pastor em uma escola evangélico-luterana com a Teologia formal e institucional construída durante sua formação, vicariato e doutorado, em um contexto não-eclesiástico, com crianças, adolescentes, jovens e famílias pouco interessadas pela igreja e pela religião. Estava-se diariamente trabalhando com crianças e jovens não ligados à igreja, pessoas que viviam a vida e a religião de forma pragmática e individualizada, com pouco envolvimento ou interesse pela instituição igreja e por questões religiosas formais, resistentes às tradições clássicas da teologia e às questões ortodoxas bíblicas e teológicas. Ao mesmo tempo, percebia-se nesse contexto grande abertura para mensagens sobre sentido da vida, busca por formas mais amplas de espiritualidade e de mística na superação de crises e angústias.

Desenvolvia-se ali o trabalho de aconselhamento e de orientação confessional, mais voltado para os professores e equipe pedagógica. As atividades pastorais com os alunos consistiam de abordagens temáticas em sala de aula ou em momentos celebrativos, como cultos e meditações. Com esse público, as abordagens mais tradicionais não funcionavam. Com as crianças 
e com os adultos, recursos da tradição eclesiástica como as histórias bíblicas e festividades do calendário litúrgico e civil tinham bons resultados. Com grupo etário do meio, porém, adolescentes e jovens, entre 10 e 17 anos, o desafio era gigantesco. Com estes, carecia-se de outra forma de aproximação, de outra teologia, que não só lhes comunicasse algo, mas que fosse ao encontro de sua busca por sentido e significado. Então os estudos e pesquisas sobre o estranho diálogo entre teologia e cultura pop e sobre religião vivida que o autor ouvira na Alemanha despontaram como uma possível solução na tarefa ministerial. Percebia-se que era possível falar com o grupo etário do meio a partir dos conteúdos que eles conheciam e valorizavam, como filmes, jogos eletrônicos, propagandas, tendências da moda, literatura, personagens e conteúdo da internet. A partir desses recursos, não só se tornou possível conversar, mas o que era dialogado fazia sentido. Além disso, o próprio autor descobria nos materiais e recursos da cultura pop e midiática uma riqueza teológica nova fascinante. A escola e o pastorado escolar era, pois, um autêntico espaço para uma religião vivida. ${ }^{1}$

A investigação sobre religião vivida nesse artigo é, portanto, não apenas teórica e especulativa, mas está relacionada a uma prática concreta, sendo, assim, um aporte para a teologia prática e a prática da igreja. Uma pergunta que permanece como pano de fundo é em que medida a realidade de mudança religiosa percebida no universo da escola acima descrito não tem se estendido para dentro da Igreja e da sociedade brasileira como um todo. No caso de grandes fatias de culturas jovens, cada vez mais ausente nas atividades clássicas de igrejas históricas do Brasil, isso já é uma realidade, como pesquisas têm indicado (ADAM; HANKE, 2014).

Pretende-se neste artigo, portanto, como já mencionado acima, definir religião vivida em sua relação com a teologia prática levando em conta as mudanças ou, pelo menos, a mudança de percepção, na religião, na cultura e na sociedade nas últimas décadas, considerando em especial o contexto brasileiro e latino-americano e buscando apontar possibilidades de uma teologia prática em diálogo com a religião vivida que contribua para repensar o papel da Igreja em um contexto carente de sentido e transformação social. $\mathrm{O}$ artigo está organizado da seguinte forma: Primeiramente, aborda-se aspectos da mudança nas pesquisas sobre religião e cultura, como pano de fundo do que veio posteriormente a definir-se como religião vivida. Em seguida, se trata de conceituar religião vivida na sua relação com a teologia prática. No terceiro ponto do artigo, reflete-se sobre as possibilidades de uma religião vivida no contexto brasileiro e latino-americano. Por fim, se apresenta algumas consequências desse estudo para a teologia prática.

\footnotetext{
${ }^{1}$ Relato sobre essa experiência com o conceito da religião vivida, encontra-se no estudo sobre Teologia em movimento (ADAM, 2018).
} 


\section{Religião, cultura e contexto em mudança - o pano de fundo da religião vivida}

O pano de fundo do conceito de religião vivida nasce de uma mudança na cultura e na sociedade e, ao mesmo tempo, de uma mudança nas teorias e pesquisas em especial da Sociologia da Religião, no século XX. Trata-se de uma virada cultural, onde as perspectivas empíricas, culturais e hermenêuticas terão papel preponderante (HERMANN, 2007, p. 45; MCGUIRE, 2008, p. 3s; AMMERMAN, 2007, p. 3s). Estas mudanças são articuladas a partir de novos pressupostos na pesquisa sociológica e são assimiladas pela Teologia em grande medida por uma mudança no papel da Igreja e na relação das pessoas com a religião e a Igreja, especialmente, no contexto europeu, pós-industrial (HERMANN, 2007, p. 45). De modo geral, diante das profundas mudanças na visão de mundo e de realidade, a pluralização, a diversidade, a globalização e, ao mesmo tempo, a individualização das concepções e compreensões da vida, os modelos tradicionais e institucionais da religião não conseguem responder de forma plena, segura e efetiva aos permanentes anseios humanos pela razão da existência (GRÄB, 2000, p. 23s).

Thomas Luckmann, no final da década de 60, lançou um pequeno livro em forma de ensaio, chamado a Religião Invisível (2014), no qual busca a partir da Sociologia ampliar o conceito de religião para além da Sociologia da religião, abarcando em sua conceituação outras formas do religioso na sociedade moderna. Segundo o autor, a secularização não significou a superação do religioso e da religião tanto na sociedade quanto na mentalidade das pessoas (BERGER, 2001, p. 10), mas sim, uma mudança e ampliação da vivência religiosa em forma de uma religião sincrética, secular e privada, algo que a pesquisa empírica sobre a religião teria que levar em conta. O deslocamento da religião para fora daquilo que a sociologia definia como religião, se dá, basicamente, por uma liberdade que o indivíduo moderno terá para organizar sua compreensão e vivência da religião independente apenas das determinações socioestruturais (HÖHN, 1996; LUCKMANN, 2014).

O ensaio sobre a religião invisível leva Luckmann a uma definição funcionalista e antropológica da religião, segundo a qual, na religião o ser humano transcende o ser biológico para tornar-se humano. Ou seja, o fenômeno religioso faz parte do processo de socialização do ser humano, na objetivação de experiências subjetivas e na individuação de cada um. No seu pós-escrito, o autor dirá:

Continuo sendo da opinião de que a função básica da "religião" consiste em transformar membros de uma espécie natural em protagonistas no interior de uma ordem social surgida historicamente. Religião é encontrada em todo lugar onde o comportamento dos membros da espécie se transforma em ações moralmente avaliáveis, onde um Self está num mundo povoado por outros 
seres, para os quais e contra os quis agirá de forma moralmente avaliável (LUCKMANN, 2014, p. 138).

A ideia da religião invisível irá ganhar na sociologia muitos outros nomes como religião moderna, religiosidade difusa, individual, civil, popular, midiática (HERRMANN, 2007; GRÄB, 2002), cotidiana (AMMERMAN, 2007) ou mesmo religião vivida (MCGuire) e irá possibilitar que a pesquisa da sociologia da religião olhe não só para fora das expressões religiosas tradicionais e institucionais, mas também repense as próprias conceituações fechadas e objetivas de religião (ASAD, 1993; VAN DE PORT, 2011). A maneira como as pessoas vivem, experimentam e expressam convicções e compreensões religiosas passa a ter valor, seja no âmbito da própria religião, seja no cotidiano, no mundo do trabalho e dos negócios, no consumo, no lazer e no entretenimento, na busca por qualidade de vida e saúde, nas novas compreensões de espiritualidade (STREIB; DINTER; SÖDERBLOM, 2008). Como McGuire pergunta:

Estudiosos da religião, especialmente sociólogos, precisam reexaminar suas suposições sobre a vida religiosa dos indivíduos. O que poderíamos descobrir se, em vez de olhar para a afiliação ou participação na organização, nos concentramos nos indivíduos, nas experiências que eles consideram mais importantes e nas práticas concretas que compõem sua experiência e expressão religiosas pessoais? E se pensarmos na religião, no nível individual, como um amálgama sempre mutante, multifacetado, muitas vezes confusa - e mesmo contraditória - de crenças e práticas que não são necessariamente consideradas importantes pelas instituições religiosas? (2008, p. 4, tradução nossa).

Neste artigo não vamos trabalhar com um conceito de religião ${ }^{2}$ como conjunto ou sistema de valores, crenças, ritos e símbolos em torno ao transcendente ou numinoso, mas sim tratar do conceito de religião vivida, entendo que este não equivale àquele. Religião vivida é uma forma de perceber a religião na sua vivência prática, cotidiana, cultural, de forma dinâmica e contextual, abastecendo as pessoas de um sentido para viver (GRÄB, 2000, p. 13s). Consideramos importante, portanto, aquelas pesquisas que abrem a conceituação da religião para as vivências individuais e práticas que equivalem ou se aproximam daquilo que de forma ampla entendemos por religião. Neste sentido consideramos importante, portanto, os estudos específicos sobre religião vivida, além das de Luckmann (HÖHN, 1996; LUCKMANN, 2014); Asad (1993), Van de Port (2011), que discordam da visão da religião como essência transhistórica, isolada e atemporal. Religião seria muito mais algo que jaz na compreensão e vivência das pessoas e que, portando, muda com o tempo, com a cultura e a sociedade.

\footnotetext{
${ }^{2}$ Segundo Pollack não há um conceito de religião universalmente aceito e válido pelos mais diversos estudos da religião e das ciências sociais. Segundo o autor, no início do século XX pelo menos 48 definições diferentes tentavam definir religião: POLLACK, D.; ROSTA, G. Religion in der Moderne: ein internationaler Vergleich. Frankfurt/New York: Campus Verlag, 2015. p. 48.
} 


\section{Religião vivida e a teologia prática}

Essas mudanças no âmbito da sociologia da religião terão impacto também na teologia prática, principalmente a partir da pergunta pela relação entre a Teologia, a cultura e o indivíduo. Importante observar que na Teologia já havia pelo menos uma articulação de correlação entre a teologia e a cultura, a Teologia da cultura de Paul Tillich (2009). As mudanças referidas levam agora não apenas à pergunta por uma correlação entre cultura e religião, mas à grande pergunta se a religião existe e vive fora dos conceitos e além das instituições, como a Igreja. Pode-se identificar fenômenos religiosos em espaços que não se entendem como religiosos, mas que, a partir de uma perspectiva teológica-religiosa possam assim ser entendido?

O conceito de religião vivida na teologia prática aparece como uma forma de corroborar que, sim, há formas de uma religião vivida no cotidiano, na cultura, na individualidade e histórias de vida de pessoas, por vezes conscientes e relacionadas à determinada religião tradicional, outras vezes inconscientes e experimentadas sem uma conotação religiosa por parte da pessoa e de grupos humanos. A teologia prática, entendida agora como teoria da prática religiosa (STECK, 2000, p. 100), irá se interessar por essas manifestações, como forma de se repensar a si mesma e o papel da igreja na atualidade. A religião vivida é, então, entendida como uma forma de olhar e de perceber a religião e a teologia não em primeiro lugar a partir de suas concepções teóricas, dogmáticas e a partir da tradição da Igreja, mas, sim, a partir daquilo que a cultura e que as pessoas fazem e dizem ser religião e o religioso, como apontam Ganzevoort e Roeland:

Os conceitos de práxis e religião vivida concentram-se no que as pessoas fazem, e não na religião "oficial", suas fontes sagradas, seus institutos e suas doutrinas. Como tal, a teologia prática tem muito em comum com o que, em disciplinas como antropologia, sociologia e estudos de mídia, é conhecida como "a virada prática": o afastamento das instituições e textos (cultural) para as práticas sociais e culturais cotidianas das pessoas (GANZEVOORT; ROELAND, 2014, p. 93, tradução nossa).

Religião vivida é uma forma de perceber elementos, conteúdos e formas religiosas na esfera da vida, sejam nas vivências cotidianas e pessoais, sejam em momentos especiais de comemoração ou de crises, nas relações diversas, no lazer e entretenimento, ou seja, fora da alçada da instituição religiosa, fora do culto, fora da própria esfera sagrada e fora da religião institucional, mesmo que, por vezes, relacionada a ela, como forma de explicar a própria vida.

Essa orientação empírica tem como consequência que a atitude adotada é mais descritiva e analítica do que normativa. [...] a dimensão textual da religião é entendida em termos de teoria cultural, como um sistema cultural de codificação de significado, com cuja a ajuda as pessoas interpretam suas vidas" (HERMMANN, 2007, p. 46, tradução nossa). 
As possibilidades de perceber esta manifestação do religioso vivido pode se dar no âmbito de uma tradição religiosa, como a Igreja, avaliando como as pessoas interpretam e vivem a religião independente da instituição e seus preceitos, mas também sem uma relação com determinada religião.

Essa segunda possibilidade tem a ver com manifestações na cultura, na mídia e no cotidiano, em elementos, conteúdos e formas, onde se percebe relações com elementos religiosos, como aponta Gräb, “a religião vivida, também a religião cristã vivida, não se encontra simplesmente apenas na Igreja" (GRÄB, 2000, p. 39, tradução nossa). Estas relações podem ser mais explícitas, como referências a conteúdos e práticas religiosas - letras de músicas da Banda U2 a partir de referências bíblicas (Música 40, por exemplo), ou o filme Noé (DARREN ARONOFSKY, 2014), baseado na relato bíblico do dilúvio, ou manifestações mais implícitas do religioso, que podem ser interpretadas como um equivalente religioso - como a devoção à cantora Madona ou o turismo a lugares de memória, como a casa de Anne Frank, em Amsterdam -, como uma nova forma de religião.

Para Gräb, essa religião vivida pode ser percebida na comunicação como expressão por sentido e significado para a existência.

A religião vivida surge na comunicação [...]. Seu conceito atua como uma "categoria de interpretação humana". E a sua realidade histórica resulta das interpretações culturais e, portanto, mas não apenas, mediadas pela Igreja institucional, como aquilo que tem com este mundo e com as nossas vidas caráter último, como de onde viemos e para onde vamos. Ela é religião vivida ali, mas também em todos os lugares, onde formas de interpretação da vida, mediadas socioculturalmente em suas práticas, atravessam como algo co-determinante e orientador (GRÄB, 2000, p. 39, tradução nossa).

Para esse autor, a busca humana por sentido e significado para a vida, principalemnte através de relações e pertencimentos - "Sentido é relação, é contexto, é conexão"3 (GRÄB, 2000, p. 13, tradução nossa) - se dá em um contexto de perda de referenciais de valores, por um lado, e a pressão por garantir uma vida plena diante de uma diversidade de ofertas de papéis a serem desempenhados, por outro lado. Nesse sentido, também o referencial da fé cristã, que por gerações abasteceu pessoas de um sentido, fica fragilizado hoje como chave-mestra diante da diversidade de ofertas e possibilidades de sentido (GRÄB, 2000, p. 14, 42s; GRÄB, W.; et al., 2006, p. 17s). Failing e Heimbrock, mesmo que mais concentrados na prática cristã no cotidiano, irão corroborar essa proposta reforçando a percepção (Wahrnehmung) como princípio básico para a atual teologia prática (FAILING; HEIMBROCK, 1998). Segundo esses autores, o motivo que leva a esta proposta tem relação com a perda de relevância da Teologia como um

3 “Sinn ist Beziehung, ist Zusammenhang, ist Verbundenheit." Texto original. 
todo na atualidade, por um lado, e a relevância do cotidiano, por outro lado, principalmente a partir da obra de Henning Luther (1992), como espaço de experiência da religiosidade do sujeito na busca por sentido e transcendência dentro da imanência da vida.

Importante observar que a religião vivida não está relacionada apenas como formas implícitas da religião e do religioso, mas tambem com formas explícitas, ou seja, avaliando a teologia que as pessoas fazem, a maneira como elas interpretam sua espiritualidade e sua vivência de Igreja (GANZEVOORT; ROELAND, 2014). Obviamente que ao tomarmos um conceito como esse, mesmo que apenas funcionalmente, estamos considerando o conceito religião como algo amplo e aberto, conforme vimos acima na perspectiva sociológica de Thomas Luckmann, da religião invisível. Em ambos os casos, portanto, a tradição e as matrizes religiosas são importantes, pois, é a partir delas que a religião vivida pode ser entendida e posta em diálogo com a própria teologia prática. Por vezes, pode-se ter a impressão que o fenômeno da religião vivida é algo novo. McGuire (2008, p. 25s) contrapõe esta ideia ao mostrar que na alta Idade Média tanto o catolicismo quanto o protestantismo não eram entidades unificadas e homogêneas e que houve projetos de consolidação de padrões teológicos e práticos sobre as crenças e vivências religiosas das pessoas, de forma autoritária. Ou seja, parece ter havido, desde sempre, inclusive anteriormente na tradição bíblica, formas de religião vivida nas margens da religião oficial.

$\mathrm{Na}$ discussão sobre a teologia prática como hermenêutica da religião vivida, Ganzevoort e Roeland se permitem definir a própria religião de forma aberta e ampla: "religião como padrões transcendentes de ação e significado, emergindo e contribuindo para a relação com o sagrado" (2014, p. 96, tradução nossa). Para os autores, essa é uma definição primariamente funcional, que tem por objetivo a máxima maleabilidade para que possamos estar abertos a novas e a diferentes formas de religião (GANZEVOORT; ROELAND, 2014). Para eles, padrões de transcendente não deveriam ser confundidos com um ser transcendente, mas sim com processos de transcendentimento das fronteiras, na relação com algo que nos envolve completamente. Para Luckmann, transcendência é exatamente aquilo que ultrapassa a evidência imediata da experiência do mundo da vida (LUCKMANN, 2014, p. 138). O cerne da definição de Ganzevoort e Roeland, entretanto, é a relação com o sagrado, o qual não é um conceito infinitamente aberto. Para Ganzevoort e Roeland, a noção do sagrado pelo menos implica um centro ao redor do qual nossa vida gravita, bem como uma presença que evoca reverência e paixão. Isso muitas vezes é determinado pelo contexto cultural no qual vivemos e segue o modelo de uma tradição religiosa (GANZEVOORT; ROELAND, 2014, p. 98).

Enquanto conceito, deve-se ainda dizer que, desde de seu início, a religião vivida foi tratada como um conceito complexo e controvertido, como dirá Rössler: "a religião vivida permanece 'indefinida', vaga, incontrolável e 
difícil de delimitar" (RÖSSLER, 1976, p. 67, tradução nossa). Surge como tentativa de contemplar as mudanças em curso, apresentadas no ponto anterior, principalmente na teologia prática. Ultilizar a hermenêutica da religião vivida e reconhecer o fenômeno da religião vivida significa encarar o risco de pensar a religião e a Teologia para além do que se padronizou com um sistema ou uma verdade.

Além disso, para a teologia e a teologia prática a religião vivida não passa de uma hermenêutica contextual da mudança da religião e da cultura, uma leitura das manifestações e vivências individuais de pessoas, da busca por sentido e significado expressos através da estética e da comunicação, para num segundo momento, dialogar com a base de sentido, com a comunicação e a tradição da Teologia e da Igreja, como aponta Gräb: "A hermenêutica religiosa e teológico-prática é a orientação da vida da Igreja e dos cristãos em sua deserção. Ela deve, portanto, sempre estabelecer relação entre a religião vivida, relacionada aos seus significados plurais e esclarecedores, e a oferta tradicional de sentido da fé cristã" ${ }^{4}$ (GRÄB, 2000, p. 45, tradução nossa).

\section{Religião vivida e religião no Brasil e América Latina}

Diferente do contexto europeu, onde surge o conceito da religião vivida, marcado por um certo secularismo e individualização da religião, a realidade brasileira é marcada não só pela religião e a Igreja, mas principalmente pela exposição da religião nas formas tradicionais e populares, em todas as esferas da vida. Quando em 1500 os portugueses invadiram o território onde hoje é o Brasil rezaram uma missa, evento emblemático para a religião e seu desenvolvimento posterior. Apesar dessa inscrição litúrgica católica, não apenas a forma oficial da fé cristã católica prevaleceu no contexto, mas também, desde o início, formas de sincretismo religioso com as religiões indígenas e, mais tarde, com as religiões de matriz africana irão marcar profundamente o contexto religioso do Brasil: miscigenação cultural e religiosa sui generis e efervescente. $\mathrm{O}$ aporte religioso dos protestantismos nesse cenário de mistura religiosa dá-se muito mais tarde (início do séc. XIX), e com os pentecostalismos (início do séc. XX). Esses movimentos irão fazer parte desse hibridismo e miscigenação religiosos, mesmo quando os contrapondo.

No Brasil - e, guardadas as diferenças de outros países da América Latina - vive-se no dia-a-dia os efeitos dessa diversidade, do hibridismo e da efervescência religiosa. Vive-se aqui um excesso de religião que excede o próprio campo religioso. A religião faz parte da cultura, da sociedade, da

\footnotetext{
4 "Der praktisch-theologischen Religionshermeneutik ist die Orientierung des Lebens der Kirche und der Christen in ihr aufgegeben. Sie muss deshalb die gelebte und in ihren pluralen Sinngehalten von ihr aufzuhellende Religion immer auch auf das tradierte Sinndetungsangebot des christlichen Glaubens beziehbar machen."
} 
intimidade, do corpo, da sexualidade, da política e da economia, da cultura pop, do cotidiano. Além do surpreendente surgimento de novas igrejas e de movimentos religiosos, nas últimas décadas, sincretismo, hibridismo e bricolagem religiosa, mobilidade religiosa fazem parte das tendências visíveis no campo religioso. ${ }^{5}$ No caso dos evangélicos, que Peter Berger (2001) irá chamar em seu texto sobre dessecularização do mundo de "explosão evangélica," significante é o dado que "já no início da década de 1990, uma nova igreja era fundada a cada dia útil apenas no Grande Rio" (REBLIN; SINNER, 2012, p. 232).

Por outro lado, estudos recentes apontam para um significante decréscimo das denominações históricas, como o luteranismo e o catolicismo (PIERUCCI, 2004), além de um crescente desinteresse pelas formas mais tradicionais de religião, principalmente o cristianismo, como vimos na introdução sobre a experiência com adolescentes e jovens no pastorado escolar. Nessa tendência, cresce consideravelmente, p. ex., o grupo dos sem-religião, segundo pesquisas do censo (RIBEIRO, 2013). Ligado ou não a essa tendência de certa secularização e decréscimo religioso, a adesão às práticas e vivências da cultura pop, principalmente de públicos jovens, como futebol, cinema, TV, entretenimento, moda, internet e música são virulentas no Brasil. Em que medida as pessoas buscam nestes meios algo também religioso ou um equivalente ao religioso é algo a ser investigado.

Seria possível falar de uma religião vivida neste contexto? Certamente que sim, considerando suas peculiaridades. Acredito que podemos falar de religião vivida no contexto brasileiro levando em conta tanto as religiosidades populares, quanto o sincretismo e o hibridismo religioso, quanto as manifestações explícitas e implícitas do religioso no cotidiano, na mídia, na cultura e na cultura pop. No que se refere ao primeiro caso, Adilson Schultz pensa a estrutura teológica brasileira a partir do imaginário religioso, o qual ele define como uma nebulosa. ${ }^{6}$ Ele usa o termo nebulosa por entender que não há uma base única sobre a qual se constroem as religiões ou a matriz religiosa brasileira, mas sim um conjunto complexo e interligado de significações entre as religiões e suas matrizes (SCHULTZ, 2008, p. 31). Para ele, no mínimo três referências abastecem esta nebulosa.

A matriz religiosa brasileira tem como principais referências as significações religiosas oriundas do catolicismo, das religiões afro-brasileiras e do espiritismo

\footnotetext{
${ }^{5}$ Dentro do contexto da globalização e da destradicionalização os estudos de Oneide Bobsin exploram o fenômeno de trânsito religioso, sincretismos, transgressão de fronteiras religiosas: BOBSIN, O. O subterrâneo religioso da vida eclesial. Estudos Teológicos, São Leopoldo, v. 37, n. 3, p. 261-280, 1997; BOBSIN, O. Tendências religiosas e transversalidade. In: ALLTMANN, W.; ALTMANN, L. (Eds.). Globalização e Religião: desafios da fé. Quito/São Leopoldo: Clai; Ceca, 2000. p. 11s; BOBSIN, O. Sagrado e cotidiano entre luteranos brasileiros. Estudos Teológicos, São Leopoldo, v. 56, n. 2, p. 376s, 2016.

${ }^{6}$ A ideia de nebulosa de Schultz foi trabalhada no estudo sobre filmes brasileiros como uma forma de religião vivida (ADAM, 2017).
} 
- além das significações indígenas naquilo que elas têm de influência sobre umbanda, espiritismo e candomblé (SCHULTZ, 2008, p. 28).

Conforme o autor, essa nebulosa foi forjada num lento e complexo processo histórico e se faz presente sobre o país se replicando num processo contínuo de ressignificação de valores e princípios. Isso faz muito sentido na compreensão do fenômeno das diferentes formas e conteúdos de uma religião vivida. Schultz pensa a nebulosa levando em conta a teoria rizomática de G. Deleuze. Diferente de raízes, que estão conectadas a um mesmo ponto, "a lógica do rizoma opera por rupturas e interconexões ao mesmo tempo" (SCHULTZ, 2008, p. 33). Assim a ideia da nebulosa e do rizoma religioso assumem características como a crença e a presença de Deus em meio à vida, ou a ideia de que o mundo invisível, de Deus, está imbricado no mundo visível, do cotidiano das pessoas. Da mesma forma, o Diabo e o mal fazem parte do cenário cotidiano. Além de Deus e do Diabo e sua presença na vida cotidiana, outras forças e entidades compõem a nebulosa, como a crença em espíritos, a prática de sacrifícios, a comunicação com o mundo dos mortos, as formas de adoração e êxtase nos ritos cúlticos, as incorporações de entidades, as expectativas pela vida eterna, a teologia da prosperidade.

[...] uma nebulosa de ambiguidades e simultaneidades: tudo parece misturado; tudo tem mais de uma possibilidade; o bem e o mal não são facilmente discerníveis; Deus e o mal são transcendentes e, ao mesmo tempo, imanentes; Deus está na Igreja, mas também está no terreiro, a fé é confessada em alta voz, mas vive de significações subterrâneas, não reveladas" (SCHULTZ, 2008, p. 35).

Religião vivida, portanto, terá muito espaço na percepção desses fenômenos populares, de sincretismos e hibridismos. O segundo espaço onde a religião vivida pode ser observada está relacionado à cultura, ao cotidiano, à vida na sua espontaneidade, dinamicidade e necessidade. A partir da década de 1960 com a articulação de uma teologia mais contextualizada no contexto latino americano, a Teologia da Libertação, surge na América Latina uma percepção, o interesse pela realidade e pela manifestação da religião para além do âmbito institucional. O método ver-julgar-agir, como processo analítico, hermenêutico e prático, deslocava o fazer teológico para a vida concreta, para a prática, principalmente onde se sofria a opressão, a miséria econômica e a discriminação do pobre, da mulher, dos negros e indígenas. Fazer teologia significava considerar e transforma - essa realidade: "A presença da Igreja na sociedade não se faz apenas mediante a prática religiosa (devocional, cúltica, litúrgica); importa articular com ela também práticas éticas, sociais e de promoção do homem todo e de todos os homens" (BOFF, 1979, p. 13). Teologia parte da prática e retorna à prática da vida.

Da preocupação econômica, social e política, as teologias da libertação irão nas décadas seguintes ampliar e ao mesmo tempo especificar seu olhar. As teologias de gênero, por exemplo, irão dar grande atenção para 
o cotidiano. Em anos recentes a teóloga feminista Ivone Gebara, p. ex., contrapõe uma epistemologia da vida ordinária à epistemologia reflexiva, filosófica e científica, advogando o conhecimento cotidiano, principalmente das pessoas em situação de vulnerabilidade e invisibilidade, como ponto de partida para uma autêntica teologia da vida: "O lugar originário da teologia não é logos sobre Deus, mas a experiência humana na complexidade de suas vivências e na sua irredutibilidade a uma razão explicativa única" (NEUENFELDT; BERGESCH; PARLOW, 2015, p. 37).

Na relação com o cotidiano, a arte e a cultura, o teólogo Rubem Alves articularia de forma muito explícita uma forma de religião vivida, uma teologia que se desdobra na vida simples e concreta. Segundo Alves, a religião nasce da necessidade do ser humano imaginar possibilidades que rompam com a dureza da realidade da vida. Segundo ele "a religião é a proclamação da prioridade axiológica do coração sobre os fatos brutos da realidade [...] em nome de uma visão, de uma paixão, de um amor" (ALVES, 1988, p. 19). Para Alves a teologia permeia o cotidiano e está entrelaçada na vida comum, na espiritualidade e religiosidade do sujeito nos mais diferentes espaços da vida, como forma de dar sentido e beleza à vida.

[...] para aqueles que amam, a teologia é uma função natural como sonhar, ouvir música, beber um bom vinho, chorar, sofrer, protestar, esperar... Talvez a teologia nada mais seja que um jeito de falar sobre tais coisas dando-lhes um nome e apenas distinguindo-se da poesia porque a teologia é sempre alheia como uma prece... Não, ela não decorre do "cogito" da mesma forma como poemas e preces. Ela simplesmente brota e se desdobra, como uma manifestação de uma maneira de ser: "suspiro da criatura oprimida" - seria possível uma definição melhor? (ALVES, 1985, p. 21)

Ainda na década de 80, o antropólogo holandês André Droogers, então vivendo no Brasil, escreveu um pequeno texto, propondo a existência no Brasil daquilo que ele chamou de Religiosidade Mínima Brasileira (RMB). "Trata-se de uma religiosidade que se manifesta publicamente em contextos seculares, que é veiculada pelos meios de comunicação de massa, mas também pela linguagem cotidiana. Ela faz parte da cultura brasileira" (DROOGERS, 1987, p. 65). Esta RMB tem grande semelhança com o que entendemos como religião vivida, no sentido de que Droogers considera como um conjunto de expressões religiosas e espirituais presentes no cotidiano da cultura brasileira e formas livres, gerais com que as pessoas expressam suas crenças e pertencimentos, independentes das instituições religiosas. $\mathrm{O}$ autor analisa essa $\mathrm{RMB}$ na política, no esporte, na Tv, no rádio, na propaganda, em frases de para-choques, na linguagem cotidiana e nos ditos populares.?

[...] a RMB não é o acervo ou mesmo matéria-prima da qual as religiões tiram seu repertório. [...] ela também não existe em função de outras religiosidades e

\footnotetext{
${ }^{7}$ Algo semelhante faz Hermann Brandt em Gottesgegenwart in Lateinamerika: Inkarnation als Leitmotiv der Befreiunstheologie. Hamburg: Steinmann\&Steinmann, 1992.
} 
religiões, todas mais específicas que ela. [...] A RMB não depende de sacerdotes-tradutores. Também não é relevante se as religiões a reconhecem ou não. [...] A RMB não tem clero, a não ser as pessoas que são os seus porta-vozes. Ela não tem escritura sagrada, a não ser os jornais e as revistas. Rituais são raros, mas talk shows na televisão podem acabar se tornando cultos da RMB. Ela não conhece hinos, a menos que certas músicas de Roberto Carlos sejam vistas assim (DROOGERS, 1987, p. 65s).

Outra investigação que pode ser associada à religião vivida são os estudos pós-coloniais da segunda metade do século XX. Recém nas últimas décadas, a teologia prática tem realizado parte de suas investigações nessa perspectiva. ${ }^{8}$ Aquilo que chamamos de religião vivida, porém, se enquadra muito bem nos estudos pós-coloniais, na medida em que rompe com os conceitos absolutos e fechados no campo da religião e passa a dar mais atenção a prática vivida pelas pessoas. Mais que um conceito, os estudos pós-coloniais representam uma nova maneira de perceber a realidade local (e global) a partir de suas diferenças, sutilezas, diversidades, fragmentaridades, alteridades, rompimentos e alternativas sociais, culturais, corporais, sexuais, políticas e religiosas, e não apenas do estabelecido e do padronizado.

[...] hablar de poscolonialidad significa cuestionar y deconstruir las dinámicas de identificación que ambicionan las fuerzas coloniales, exponiendo sus proprias debilidades a través de las heterogeneidades inscriptas en tal Sujeto, con la intención de visibilizar las intrínsecas bifurcaciones que cartacterizan el contexto global, las cuales permiten su constante maleabilidad, transformación y apertura hacia nuevas formas de construción sociocultural (PANOTTO, 2016, p. 34s).

Penso que aqui há grande potencialidade para pensarmos religião vivida no contexto latino-americano, uma vez que a pos-colonialidade intensifica o olhar para a cultura, o cotidiano, o corpo, acentuando em especial a diferença, aqueles aspectos que não se enquadram nos padrões homogêneos dos sistemas e das verdades absolutas e que por isso são vistos com débeis, frágeis e vulneráveis. ${ }^{9}$

\section{Conclusão: Consequências de uma hermenêutica da religião vivida para a teologia prática}

A teologia prática pode ser entendida como a reflexão crítica sobre a práxis, sobre teorias e percepções da prática com vistas à comunicação do Evangelho ao mundo. Nesse sentido, a hermenêutica da religião é uma forma imprescindível para entender o a sociedade, a cultura e o

\footnotetext{
${ }^{8}$ Em abril de 2019 ocorre na Faculdades EST, em São Leopoldo/RS, Brasil, a conferência da Academia Internacional de Teologia Prática (IAPT) sobre o tema "Decolonialidade e práticas religiosas: libertando a esperança", reunindo mais de cem acadêmicos de todos os continentes, como pode ser conferido no site da academia: https://www.ia-practicaltheology.org/

${ }^{9}$ Esta discussão sobre a teologia normativa e sobre a teologia vivencial requer um aprofundamento. Sugiro para tal iniciar com a discussão de Matitijs van de Port, em seu livro Ecstatic
} 
ser humano e suas formas e jeitos de vivenciar e compreender a vida e o papel da religião nesse seu exercício de viver. A religião vivida é uma forma de observar a realidade religiosa da pessoa, num primeiro momento, para, a partir dessa observação, fazer o caminho de volta para dentro da comunicação do Evangelho, levando em conta a herança teológica, bíblica, histórica, bem como a tradição da Igreja. A hermenêutica da religião vivida não se encerra em si, mas serve de instrumento para refletir sobre a religião prática de indivíduos, culturas e sociedades.

Nesse sentido, pode-se perceber na hermenêutica da religião vivida no mínimo três grandes consequências para a teologia prática. 1) A religião institucional, a Igreja, já não oferece todo o sentido para a vida de pessoas e sociedades hoje, como dirá Gräb, "A fé cristã não nos dá mais nenhuma informação sobre o que está acontecendo em um sentido objetivamente válido com o mundo como um todo e a história da humanidade na minúscula pequena terra à beira do vasto universo" (tradução nossa / GRÄB, 2000, p. 17). A busca humana por sentido, porém, permanece. 2) Faz-se necessário entender outras formas de oferta de sentido presentes na sociedade individualizada, plural, vivencial e pragmática em que vivemos. A religião vivida nas suas mais variadas formas expressa e dá forma à busca humana por sentido e significado para vida. A religião vivida permite, assim, repensar formas de como a teologia prática pode auxiliar o ser humano a reencontrar sentido que a fé cristã oferta. Por último, 3) observar a religião vivida em suas formas implícitas e explícitas é uma forma de ampliar a própria teologia prática enquanto disciplina e reinventar novas formas de evangelização, missão, vivência da fé cristã no mundo de hoje.

\section{Sigla}

RMB - Religiosidade Mínima Brasileira

\section{Referências}

ADAM, J. C. Deus e o diabo na terra do sol: religião vivida, conflito e intolerância em filmes brasileiros. Estudos de Religião, São Paulo, v. 31, n. 2, p. 77-99, maio/ ago. 2017.

. Teologia em movimento: perspectivas da teologia prática como hermenêutica da religião vivida a partir do cinema brasileiro. Numen, Juiz de Fora, v. 21, n. 1, p. 114-128, jan/jun. 2018.

encounters: Bahian Candomblé and the Quest for the Really Real. Amsterdam: Amsterdam University Press, 2011 e de Nícolas Panotto, em seu livro Religión, Política y Poscolonialidad en América Latina: hacia una teología posfundacional de lo público. Madrid; Buenos Aires: Miño y Dávila, 2016. 
. HANKE, E. Juventude midiatizada: um estudo sobre as possibilidades de uma religião vivida na e através da mídia. Revista de Teologia e Ciências da Religião, Recife, v. 4, n.1, p. 213-236, 2014.

ALLTMANN, W.; ALTMANN, L. (Eds.). Globalização e Religião: desafios da fé. Quito; São Leopoldo: Clai; Ceca, 2000.

ALVES, R. Variações sobre a vida e a norte: o feitiço erótico-herético da teología. 2.ed. São Paulo: Paulinas, 1985.

O enigma da religião. 4ed. Campinas: Papirus, 1988.

AMMERMAN, N. T. (Ed.). Everyday religion: Observing modern religious lives. New York: Oxford University Press, 2007.

ASAD, T. Genealogies of Religion: Discipline and Reasons of Power in Christianity and Islam. Baltimore; London: The Johns Hopkins University Press, 1993.

BERGER, P. A dessecularização do mundo: uma visão global. Religião e Sociedade, Rio de Janeiro, v. 21, n.1, p. 9-23, abr. 2001.

BOBSIN, O. O subterrâneo religioso da vida eclesial. Estudos Teológicos, São Leopoldo, v. 37, n. 3, p. 261-280, 1997.

Sagrado e cotidiano entre luteranos brasileiros. Estudos Teológicos, São Leopoldo, v. 56, n. 2, p. 376-392, 2016.

BOFF, L. Da libertação: o teológico das libertações sócio-históricas. Petrópolis: Vozes, 1979.

BRANDT, H. Gottesgegenwart in Lateinamerika: Inkarnation als Leitmotiv der Befreiunstheologie. Hamburg: Steinmann \& Steinmann, 1992.

CALVANI, C. E. Teologia e MPB. São Bernardo do Campo; São Paulo: UMESP; Loyola, 1998.

DROOGERS, A. A religiosidade mínima brasileira. Religião e sociedade, Brasil, $\mathrm{n}$. 14, v. 2, 1987.

FAILING, W.-E.; HEIMBROCK, H.-G. Gelebte Religion wahrnehmen: Lebenswelt, Alltagskultur, Religionspraxis. Stuttgart: Kohlhammer, 1998.

GANZEVOORT, R.; ROELAND, J. Lived Religion: the praxis of practical theology. International Journal of Practical Theology, 18(1), p. 91-101, 2014.

GRÄB; W. Auf den Spuren der Religion. Zeitschrift für Evangelische Ethik, Bochum, n. 39, p. 43-56, 1995.

. Lebensgeschichten, Lebensentwürfe, Sinndeutungen: eine praktische Theologie gelebter Religion. 2.Aufl. Gütershoh: Kaiser; Gütersloher Verlaghaus, 2000.

. Sinn fürs Unendliche: Religion in der Mediengesellschaft. Gütersloh: Kaiser; Gütersloher Verlaghaus, 2002.

. Religion als Deutung des Lebens: Perspektiven einer Praktischen Theologie gelebter Religion. Gütersloh: Gütersloher Verlaghaus, 2006.

GRÄB, W. et al. Irgendwie fühl ich mich wie Frodo: eine empirische Studie zum Phänomen der Medienreligion. Frankfurt am Main; Berlin; Bern; Bruxelles; New York; Oxford; Wien: Peter Lang, 2006. 
GUTMANN, H.-M. Der Herr der Herrscharen, die Prinzessin der Herzen und der König der Löwen: Religion lehren zwischen Kirche, Schule und populärer Kultur. Gütersloh: Gütersloher Verlaghaus, 1998.

. "Irgendwas ist immer": Durchs Leben kommen. Sprüche und Kleinrituale, die Alltagsreligion der Leute. Berlin: EB; Verlag, 2013.

HERRMANN, J. Medienerfahrung und Religion: eine empirische-qualitative Studie zur Medienreligion. Göttingen: Vandenhoeck \& Ruprecht, 2007.

HÖHN, H.-J. (Ed.). Krise der Immanenz: Religion an den Grenzen der Moderne. Frankfurt am Main: Fischer, 1996.

KUNSTMANN, J.; REUTER, I. (Eds.). Sinnspiegel: theologische Hermeneutik populärer Kultur. Paderborn: Ferdinand Schöningh, 2009.

LUCKMANN, T. A religião invisível. São Paulo: Olho d'Água; Loyola, 2014.

LUTHER; H. Religion und Alltag: Bausteine zu einer Praktischen Theologie des Subjekts. Stuttgart: Raddius Teckla, 1992.

MCGUIRE, Meredith B. Lived Religion: Faith and Practice in Everyday Life. Oxford: Oxford University Press, 2008.

MAGALHÃES, A. Deus no espelho das palavras: teologia e literatura em diálogo. São Paulo: Paulinas, 2000.

NEUENFELDT, E.; BERGESCH, K.; PARLOW, M. (Orgs.). Epistemologia, violência e sexualidade: Olhares do II Congresso Latino-Americano de Gênero e Religião. São Leopoldo: Sinodal; EST, 2015.

PANOTTO, N. Religión, Política y Poscolonialidad en América Latina: hacia una teología posfundacional de lo público. Madrid; Buenos Aires: Miño y Dávila, 2016.

PIERUCCI, A. F. "Bye bye, Brasil": o declínio das religiões tradicionais no Censo 2000. Estudos avançados, São Paulo, v. 18, n. 52, sept./dec. 2004.

POLLACK, D.; ROSTA, G. Religion in der Moderne: ein internationaler Vergleich. Frankfurt; New York: Campus Verlag, 2015.

REBLIN, I. A. A Teologia do Cotidiano. In: BOBSIN, Oneide et. al. (Orgs.) Uma religião chamada Brasil. São Leopoldo: Oikos; EST, 2008, p. 82-96.

REBLIN, I. A.; SINNER, R. von. Religião e sociedade: desafios contemporâneos. São Leopoldo: Sinodal, 2012.

RIBEIRO, J. C. Sem-religião no Brasil: dois estranhos sob o guarda-chuva. Cadernos do IHU, São Leopoldo, v. 11, n. 198, 2013.

RÖSSLER, D. Die Vernunft der Religion. München: Piper Verlag, 1976.

SANTOS, J. M. G. dos. Central do Brasil - Busca, Fuga, Inversão e Encontro: a expressividade simbólico-teológica do filme a partir de uma troca de olhar entre cinema e teologia. São Leopoldo: EST, 2002.

Cinema e teologia: por que tratar de cinema numa teologia da cidade? In: ZWETSCH, R. E. (Org.). Cenários urbanos: realidade e esperança. Desafios às comunidades cristãs. São Leopoldo: Sinodal, EST, 2014, p. 241-255. 
SCHULTZ, A. Estrutura teológica do imaginário religioso brasileiro. In: BOBSIN, O. et al. (Org.) Uma religião chamada Brasil: Estudos sobre religião e contexto brasileiro. São Leopoldo: EST; Oikos, 2008, p. 27-60.

STECK, W. Praktische Theologie: Horizonte der Religion - Konturen des neutzeitlichen Christentums - Strukturen des Lebenswelt. Stuttgart; Berlin; Köln: Kohlhammer, 2000.

STREIB, H.; DINTER, A.; SÖDERBLOM, K. (Eds.) Lived religion: conceptual, empirical and practical-theological approaches: essays in honor of Hans-Günter Heimbrock. Leiden: Brill, 2008.

SÜSS, G. P. Catolicismo Popular no Brasil: tipologia e estratégia de uma religiosidade vivida. São Paulo: Loyola, 1979.

TILLICH, P. Teologia da cultura. São Paulo: Fonte, 2009.

VAN DE PORT, M. Ecstatic encounters: Bahian Candomblé and the Quest for the Really Real. Amsterdam: Amsterdam University Press, 2011.

ZWETSCH, R. E; BOBSIN, O. (Orgs.). Prática cristã: novos rumos. São Leopoldo: Sinodal; IEPG, 1999.

WESTHELLE, V. Displacing Identities: Hybrid Distinctiveness in Theology and Literature. In: HAVEA, J.; PEARSON, C. (Eds.). Out of Place: doing theology on the cross cultural brink. New York: Routledge, 2011. p. 42-64.

Artigo submetido em 15.02.2019 e aprovado em 01.07.2019.

Júlio Cézar Adam é doutor em Teologia pela Universidade de Hamburgo/Alemanha (2004), realizou pós-doutorado no Programa de Pós-Graduação em Filosofia da PUC/RS (2011-2012 - PROCAD/CAPES), professor adjunto de Teologia Prática, na Faculdades EST e coordenador do Programa de Pós-Graduação da Faculdades EST, diretor do Centro de Recursos Litúrgicos (CRL), coordenador da Rede Latino Americana de Homilética (RedLah), diretor das revistas Estudos Teológicos. Orcid.org/0000-0002-8346-1093. E-mail: julioadam@est.edu.br

Endereço: R. Amadeo Rossi, 467 93030-220 São Leopoldo/RS 